\title{
THE EFFECT OF PROBLEM BASED LEARNING MODEL ON STUDENTS LEARNING RESULTS AND STUDENTS' PROBLEM SOLVING SKILLS
}

Johannes Febriko Napitupulu ${ }^{1}$, Mariati Purnama Simanjuntak ${ }^{2}$, and Johan Sinurat ${ }^{2}$

${ }^{1}$ Department of Physics Faculty of Mathematics and Natural Sciences, Medan State University

${ }^{2}$ Science Department Faculty of Mathematics and Natural Sciences, Medan State University

St. Williem Iskandar Psr. V Medan Estate, Medan, Indonesia, 20221

* sniper96joe@gmail.com

Accepted: November $11^{\text {th }}, 2019$. Published: November $26^{\text {th }}, 2019$

\begin{abstract}
This study focused on the influence of problem-based learning (PBL) models on student learning outcomes and students' problem-solving skills, the improvement of student learning outcomes and KPM, and the improvement of each indicator. This research was quasiexperiment. The population of this study were all class X Senior High School 4 Medan totalling ten classes. Sampling was done by simple random sampling. Class $\mathrm{X}-8$ as an experimental class and class X-9 as a control class with totalling 32 students. The instrument for student learning outcomes is a multiple-choice test, and KPM was an essay test. The learning outcomes and KPM posttest in experimental class with PBL models were 77.97 and 62.78 while the control class with conventional learning was 70.3 and 41.8. Hypothesis testing shows the final learning outcomes and KPM of the two classes were different. The results concluded that there was an influence of PBL model on student learning outcomes and students' KPM, there was an improvement of PBL model on student learning outcomes and students' KPM, and an improvement in each indicator of KPM in the experimental class was bigger than conventional class.
\end{abstract}

Keywords: problem-based learning, learning outcomes, problem-solving skills 


\section{Introduction}

The development of science is greatly influencing various aspects of people's lives. The concentration of science is divided into natural science and social science. Natural science (IPA) is associated with science that discusses living things, symptoms of natural phenomena that have occurred, and systematic equations. The science concentration is divided into Physics, Biology, Chemistry, and Mathematics. Physics is an IPA branch that studies natural phenomena and symptoms empirically, logically, systematically, and rationally involving scientific processes and attitudes.

Physical subjects start from high school to college. Therefore physics subjects are very important for students to learn in education. In fact, physics subjects are very few who love it and master it, resulting in learning outcomes in lowlevel cognitive domains.

The low learning outcomes can be seen based on the results of interviews that the author has done to one of the physics teachers at the school. Based on the results of interviews, it is known that the daily test scores for each physics material in class X academic year 2015/2016 is still far from the target of expectations. The average value of daily repetitions of physics material is 70.23 with a value of 76 in academic year 2014/2015, and a value of 79.02 in academic year 2013/2014, while the passing score standard in the school of SMA N 4 Medan is 70. It turns out that the daily test scores are very low in the academic year with a value of 68.34 and experienced an increase to daily tests on academic year 2016/2017. This data shows the value of physics subjects is still low and tends to decrease.

Teachers have not applied students to be able to solve problems in physics material in daily life, causing students' problem-solving abilities to become undeveloped so that students cannot understand the use of physics material that has been taught optimally in everyday life and actually makes questions that great in students' thinking. According to Uno (2006) the purpose of learning is the end result of learning that directs students to one of the cognitive domains, attitudes and skills, besides the purpose of learning is not just knowing but also solving problems. Therefore, besides learning outcomes, students' solving abilities must also be considered by the teacher.

Problem-solving ability (problem-solving) is an effort or way of thinking and human behaviour to solve problems systematically. Based on this reality, it is necessary to apply a learning model that can optimise student learning outcomes in solving problems that exist in the physics material being taught.

According to Anderson \& Krathwohl (2001), learning outcomes are an achievement that students can get in the realm of knowledge, attitudes, and skills after experiencing the learning process, where indicators of knowledge including learning outcomes in the cognitive domain which consists of remembering, understanding, applying, analysing, evaluating and creating. Therefore, the right learning model is needed. According to Joyce, Weilv and Calhoun (2009) the learning model is a plan or pattern that is used as a guide in planning classroom learning or tutorial learning and for determining learning devices in it including books, films, computers, curriculum, etc.

One of the related learning models about a problem that can be applied is a problem-based learning model (PBL). PBL is a learning model that makes the problems faced by students as sources of information to encourage students to be more able to explore, understand and get to know the contents of the learning material. Learning models such as PBL can make students more eager to solve everyday problems related to physical matter.

According to Arends (2008), the PBL model is a learning model where students solve authentic problems to develop their knowledge, develop self-reliance and confidence, and develop higher-level inquiry and thinking skills such as problem-solving. Based on this background, the authors conducted a study to determine the effect of problem-based learning models on learning outcomes and students' problem-solving abilities.

\section{Research Methods}

This research was conducted in Senior High School 4 Medan on even semester of the academic year 2017/2018. The population in this study was all students of class X IPA. The sample in this study consisted of two classes, namely class X-8 as an experimental class, and class X-9 as a control class, each class has 32 students. The sampling technique uses simple random sampling technique.

This study involved two classes namely the experimental class and the control class that was given different treatments. The model of 
problem-based learning in the experimental class, while in the control class using conventional learning. The design of this study can be seen in Table 1.

Table1. Two Group Pretest-Posttest Design

\begin{tabular}{|l|c|c|c|}
\hline \multicolumn{1}{|c|}{ Class } & Pretest & Treatment & Posttest \\
\hline Experimental & $\mathrm{T}_{1}$ & $\mathrm{X}$ & $\mathrm{T}_{2}$ \\
\hline Control & $\mathrm{T}_{1}$ & $\mathrm{Y}$ & $\mathrm{T}_{2}$ \\
\hline
\end{tabular}

\section{For information:}

$\mathrm{T}_{1}=$ pretest before the treatment was given

$\mathrm{T}_{2}=$ posttest after the treatment was given

$\mathrm{X}=$ learning by using problem-based learning

$\mathrm{Y}=$ learning by using conventional learning.

The researcher gave the pretest to the experimental class and the control class. The instrument used in the study was a learning outcome test consisting of 15 multiple choice questions and a problem-solving ability test (KPM) consisting of 5 essay questions. Assessment of KPM test based on indicators by Nezu, Maguth, and D'Zrurilla (2007) was given in Table 2.

Table2. Indicator of KPM according to Nezu et al (2007)

\begin{tabular}{|c|l|}
\hline No. & \multicolumn{1}{|c|}{ Indikator KPM } \\
\hline 1 & $\begin{array}{l}\text { Explain the problem and gather the real } \\
\text { goals (KPM 1) }\end{array}$ \\
\hline 2 & Generate alternative solutions (KPM 2) \\
\hline 3 & Predict and develop solutions (KPM 3) \\
\hline 4 & Examine the solution plan (KPM 4) \\
\hline
\end{tabular}

Learning outcomes and KPM tests are initially standardised using the content validity test by two lecturers who are expert in it. After the pretest data was obtained, data analysis was performed with a normality test, namely Liliefors test, homogeneity test and similarity variance test. And then the researcher taught the subject matter using the PBL model in the experimental class and conventional learning in the control class. The difference in final results can be known by posttest using the t-test on learning outcomes and KPM to determine the effect of PBL model on student learning outcomes and KPM.

\section{Results and Discussions}

\section{a. Results}

Pretest data of learning outcomes aims to determine the initial ability of students both classes as shown in table 3 .
Table 3. Pretest data of learning outcomes for experimental and control class

\begin{tabular}{|c|c|c|c|}
\hline & \multirow[b]{2}{*}{ Score } & \multicolumn{2}{|c|}{ Frequency } \\
\hline & & $\begin{array}{c}\text { Experimental } \\
\text { class }\end{array}$ & Control Class \\
\hline 1. & $20-27$ & 6 & 5 \\
\hline 2. & $28-35$ & 7 & 5 \\
\hline 3. & $36-43$ & 8 & 7 \\
\hline 4. & $44-51$ & 3 & 8 \\
\hline 5. & $52-60$ & 8 & 7 \\
\hline \multicolumn{2}{|c|}{$\begin{array}{c}\text { Number of } \\
\text { students }\end{array}$} & 32 & 32 \\
\hline \multicolumn{2}{|c|}{ Average } & 40.81 & 41.69 \\
\hline \multicolumn{2}{|c|}{ Deviation standard } & 12.3 & 10.3 \\
\hline
\end{tabular}

Posttest data of learning outcomes aims to determine the final ability in both classes with different treatments, as shown in Table 4. Table 4. Posttest data of Learning Outcomes of Experimental and Control Class

\begin{tabular}{|c|c|c|c|}
\hline & \multirow[b]{2}{*}{ Score } & \multicolumn{2}{|c|}{ Frequency } \\
\hline & & $\begin{array}{c}\text { Experimental } \\
\text { Class }\end{array}$ & Control Class \\
\hline 1. & 60 & 6 & 10 \\
\hline 2. & 67 & 2 & 10 \\
\hline 3. & 73 & 5 & 5 \\
\hline 4. & 80 & 7 & 1 \\
\hline 5. & 87 & 11 & 6 \\
\hline 6. & 93 & 1 & \\
\hline & $\begin{array}{l}\text { Number of } \\
\text { students }\end{array}$ & 32 & 32 \\
\hline & Average & 77.97 & 70.3 \\
\hline & Deviation standard & 10.3 & 10.5 \\
\hline
\end{tabular}

The results of the normality and homogeneity tests of pretest and posttest data obtained normal and homogeneous distributed data. The t-test for the pretest and posttest of the learning outcomes of the two classes can be seen in Table 5 and Table 6.

Table5. Pretest Data Learning Outcomes of Experimental and Control Classes

\begin{tabular}{|c|c|c|c|l|}
\hline Pretest data & Average & $\boldsymbol{t}_{\text {count }}$ & $\boldsymbol{t}_{\text {table }}$ & Conclusion \\
\hline Experimental & 40,81 & \multirow{2}{*}{0,311} & 1,6697 & $\begin{array}{l}\text { Initial } \\
\text { cognitive is } \\
\text { the same }\end{array}$ \\
\hline
\end{tabular}

Table6. t-Test of Posttest learning outcomes of Experimental and Control classes

\begin{tabular}{|c|c|c|c|l|}
\hline Post test data & Average & $\boldsymbol{t}_{\text {count }}$ & $\boldsymbol{t}_{\text {table }}$ & Conclusion \\
\hline Experimental & 77,97 & \multirow{2}{*}{2,56} & 1,6697 & $\begin{array}{l}\text { There is a } \\
\text { significant } \\
\text { difference }\end{array}$ \\
\hline
\end{tabular}

Increase of the percentage of learning outcomes was analysed using $\mathrm{N}$-gain as shown in Table 7. 
Table7. Increase of Average and Percentage on $\mathrm{N}$-gain Learning Outcomes in Both Classes

\begin{tabular}{|l|c|c|c|c|}
\hline Class & Pretest & Posttest & $\begin{array}{c}\text { Percentage } \\
\text { of N-gain } \\
\text { learning } \\
\text { outcomes } \\
(\%)\end{array}$ & Category \\
\hline Control & 41,69 & 70,3 & 49 & Medium \\
\hline $\begin{array}{l}\text { Experim } \\
\text { ental }\end{array}$ & 40,81 & 77,97 & 62 & Medium \\
\hline
\end{tabular}

Remarks: Low $=\leq 30 \%$, Medium $=31 \%-70 \%$, High $=\geq 70 \%$

In addition to the learning outcomes data, KPM pretest data obtained which aims to determine the initial KPM in both classes, as shown in Table 8 .

Table8. Initial KPM Data in the Control and Experimental Classes

\begin{tabular}{|c|c|c|c|}
\hline \multirow{2}{*}{ Class } & \multirow{2}{*}{ Score } & $\begin{array}{c}|c| \\
\text { Control } \\
\text { Class }\end{array}$ & $\begin{array}{c}\text { Experimental } \\
\text { Class }\end{array}$ \\
\hline 1 & $5-10$ & 3 & 2 \\
\hline 2 & $10-20$ & 9 & 11 \\
\hline 3 & $20-30$ & 19 & 16 \\
\hline 4 & $30-40$ & 1 & 3 \\
\hline \multirow{4}{*}{} & $\begin{array}{c}\text { Number of } \\
\text { students }\end{array}$ & 32 & 32 \\
\cline { 2 - 4 } & Total Score & 1362 & 1335 \\
\cline { 2 - 4 } & Average & $\mathbf{2 1 . 2 8}$ & $\mathbf{2 0 . 8 6}$ \\
\cline { 2 - 4 }
\end{tabular}

Both samples were given posttest with different treatments to see the final KPM of students. The distribution of posttest data in both samples can be seen in Table 9 .

Table9. Posttest Data of Problem Solving Ability in the Control and Experimental Classes

\begin{tabular}{|c|c|c|c|c|}
\hline \multirow{2}{*}{ Class } & \multicolumn{2}{|c|}{ Control class } & \multicolumn{2}{c|}{ Experimental Class } \\
\cline { 2 - 5 } & Score & Frequency & Score & Frequency \\
\hline 1 & $11-40$ & 14 & $41-50$ & 7 \\
\hline 2 & $41-50$ & 6 & $51-60$ & 8 \\
\hline 3 & $51-60$ & 9 & $61-70$ & 10 \\
\hline 4 & $61-70$ & 3 & $71-80$ & 7 \\
\hline \multirow{2}{*}{$\begin{array}{c}\text { Number } \\
\text { of } \\
\text { students }\end{array}$} & 32 & $\begin{array}{c}\text { Number } \\
\text { of } \\
\text { students }\end{array}$ & 32 \\
\cline { 2 - 5 } & $\begin{array}{c}\text { Total } \\
\text { score }\end{array}$ & 2675 & $\begin{array}{c}\text { Total } \\
\text { score }\end{array}$ & 4018 \\
\cline { 2 - 5 } Average & $\mathbf{4 1 . 8}$ & Average & $\mathbf{6 2 . 7 8}$ \\
\cline { 2 - 5 }
\end{tabular}

The results of the normality and homogeneity test of the pretest and posttest KPM on experimental and control class were carried out as a condition before conducting hypothesis testing using the t-test, obtaining normal and homogeneous distributed data. Then the summary calculation of hypothesis testing for the pretest and posttest learning outcomes of the experimental and control class can be seen in Table 10 and Table 11.

Table 10. Pretest Data of KPM by using t-Test for Experimental and Control Class

\begin{tabular}{|c|c|c|c|c|}
\hline $\begin{array}{l}\text { Pretest } \\
\text { data }\end{array}$ & Average & $\boldsymbol{t}_{\text {count }}$ & $\boldsymbol{t}_{\text {table }}$ & Conclusion \\
\hline Experimental & 21,28 & 0,23 & 1,6697 & $\begin{array}{c}\text { Initial KPM } \\
\text { of students } \\
\text { is equal }\end{array}$ \\
\hline Control & 20,86 & 0,2 & \\
\hline
\end{tabular}

Table11. Posttest Data of KPM by using t-Test for Experimental and Control Class

\begin{tabular}{|c|c|c|c|l|}
\hline $\begin{array}{l}\text { Posttest } \\
\text { data }\end{array}$ & Average & $\boldsymbol{t}_{\text {count }}$ & $\boldsymbol{t}_{\text {table }}$ & $\begin{array}{l}\text { Concl } \\
\text { usion }\end{array}$ \\
\hline Experimental & 62,78 & & & $\begin{array}{l}\text { There } \\
\text { is a a } \\
\text { Cignifi } \\
\text { Cant } \\
\text { differ } \\
\text { ence }\end{array}$ \\
\hline
\end{tabular}

Based on pretest and posttest data, it can be seen that KPM has increased. The increase in the percentage of KPM value was analyzed using normalised gain ( $\mathrm{N}$-gain) as shown in Table 12.

Table12. Increase of Average and Percentage on $\mathrm{N}$-gain Learning Outcomes in Both Classes

\begin{tabular}{|l|c|c|c|c|}
\hline Class & Pretest & Posttest & $\begin{array}{c}\text { Percentage } \\
\text { N-gain } \\
\text { Learning } \\
\text { Result \%) }\end{array}$ & Category \\
\hline Control & 21,28 & 41,8 & 26 & Low \\
\hline $\begin{array}{l}\text { Experi } \\
\text { mental }\end{array}$ & 20,86 & 62,78 & 53 & Medium \\
\hline
\end{tabular}

For information: Low $=\leq 30 \%$, Medium $=31 \%-$ $70 \%$, High $=\geq 70 \%$

An analysis was also carried out on the value of each problem-solving indicator to see the problem-solving dimensions that are difficult for students based on problem-solving indicators. The recapitulation of the value of each problemsolving indicator in both classes can be seen in Table 13.

Table13. Recapitulation of the Value of each indicator of KPM in the Experiment and Control Class

\begin{tabular}{|c|c|c|c|c|}
\hline \multirow{2}{*}{$\begin{array}{c}\text { Indicator } \\
\text { of KPM }\end{array}$} & \multicolumn{2}{|c|}{$\begin{array}{l}\text { Experimental } \\
\text { Class }\end{array}$} & \multicolumn{2}{|c|}{ Control Class } \\
\hline & Pretest & Posttest & st & \\
\hline & 30.1 & 82. & 23.1 & 59.9 \\
\hline
\end{tabular}




\begin{tabular}{|l|c|c|c|c|}
\hline KPM 2 & 16.2 & 88 & 36.5 & 59.7 \\
\hline KPM 3 & 21.2 & 51.1 & 17.2 & 30.1 \\
\hline KPM 4 & 13.4 & 47.9 & 17.9 & 32.2 \\
\hline
\end{tabular}

Based on Table 13 the value of each problem-solving indicator has increased. The percentage increase for each problem-solving indicator was analyzed using $\mathrm{N}$-gain. The $\mathrm{N}$-gain results increase in each KPM indicator in the control and experiment classes are shown in Table 14 and Figure 1.

Table14. Average N-Gain for Each ProblemSolving Indicator in the Control and Experimental Classes

\begin{tabular}{|c|c|c|c|c|c|}
\hline & $\begin{array}{c}\text { Indicator } \\
\text { of } \\
\text { problem- } \\
\text { solving }\end{array}$ & \multicolumn{4}{|c|}{ N-Gain each indicator of Problem } \\
\cline { 3 - 6 } Solving (\%) \\
\hline 1 & KPM 1 & Control & $\begin{array}{c}\text { Categor } \\
\mathbf{y}\end{array}$ & $\begin{array}{c}\text { Exper } \\
\text { iment } \\
\text { al }\end{array}$ & $\begin{array}{c}\text { Categor } \\
\mathbf{y}\end{array}$ \\
\hline 2 & KPM 2 & 37 & Medium & 75 & High \\
\hline 3 & KPM 3 & 16 & Low & 37 & High \\
\hline 4 & KPM 4 & 17 & Low & 40 & Medium \\
\hline
\end{tabular}

For information: Low $=\leq 30 \%$, Medium $=31 \%-70 \%$, High $=\geq 70 \%$

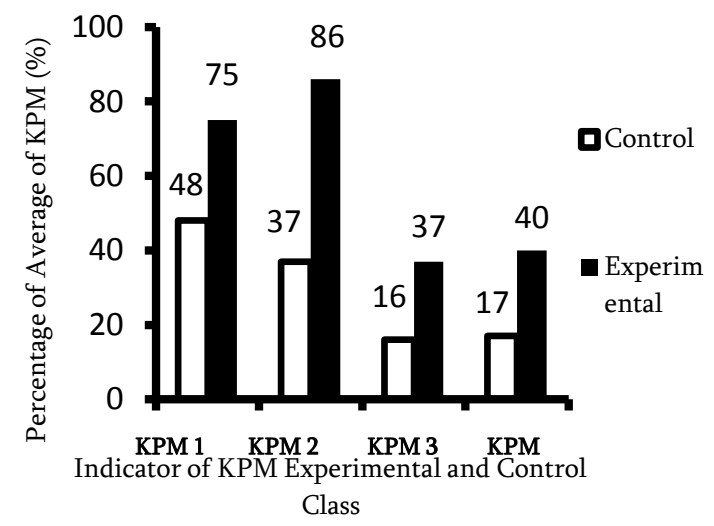

Figure1. Average N-Gain for Each Problem Solving Indicator in the Control and Experiment Classes.

\section{Discussions}

The researcher obtained the development of scores on cognitive learning outcomes and KPM of students from both classes at the end of the study. The development of higher cognitive learning outcomes is found in the experimental class compared to the control class. The development of the value of cognitive learning outcomes can be seen based on the average value of the pretest and posttest of the two classes. The average value of the pretest of learning outcomes in the experimental class cognitive domain was
40.81 while the control class 41.69 , then the average score of posttest learning outcomes in the experimental class cognitive domain was 77.97 while the control class was 70.3. Based on this data, it can be seen that the development of learning outcomes in the cognitive domain in the experimental class developed from 40.81 to 77.97 with a difference in scores between pretest and posttest of 37.91, while in the control class from 41.69 to 70.3 with a difference in value between pretest and posttest as much as 28.61. The difference between the pretest and posttest scores in each class proves that each class has development but is higher in the class treated with the PBL model.

In addition to learning outcomes in the cognitive domain, researchers also got the development of grades at the KPM of students from both classes at the end of the study. The development of higher KPM values was found in the experimental class compared to the control class. The development of the KPM value can be seen based on the average value of the pretest and posttest of the two classes. The average KPM pretest in the experimental class was 20.86 while the control class was 21.28, then the experimental class KPM post-test score was 62.78 while the control class was 41.8. Based on this data it can be seen that the average value of the KPM in the experimental class has improved better than the control class. The increase in the average KPM value of students taught with PBL learning models in the experimental class is $52 \%$ better than the class taught by conventional learning $26 \%$. Problem-solving abilities of students taught with PBL models are better than students taught with conventional learning.

The differences in learning outcomes in the cognitive domains in the students shown in the results of this study are also caused by the advantages of PBL learning models at each stage of learning, which in the first phase PBL requires students to be able to recognize, understand, identify the problems presented by the teacher, and guide students to be more interested in solving problems. The second phase of PBL, all students begin learning activities to collect the data needed to be tested. PBL Third Phase, after the data that has been collected by students, students carry out discussions, conduct experiments, and complete student worksheets, besides students, are also required to present the results or findings that students have done. PBL's fourth phase with the help of teachers, students are required to develop the results or findings they find by using their understanding, thinking, 
planning and language, so students create their works, therefore at this stage the cognitive domain. The fifth phase of PBL evaluates the problem-solving process, in this phase students who have developed the results of trials based on experiments from worksheets students are required to recheck and evaluate the results of their work so that the results of their work have answered every problem that exists.

The results of the study found that the results of the analysis of each problem-solving indicator were obtained at the stage of focusing on the problem, explaining problems in physics, planning solutions, implementing solution plans and evaluating the solutions taught with PBL learning models and conventional learning having different results. The experimental class for indicators making alternative solutions has a gain value of $86 \%$ included in the high gain criteria and the indicator developing a solution alternative has the lowest gain having a value of $37 \%$ including the medium category, while for the control class the indicator makes an alternative solution of $37 \%$ included in the category being and developing alternative solutions obtained a value of $16 \%$ including the low category.

This research is in line with the results of research conducted by Wardhani (2012) who said that learning by using the PBL model improves the ability of abstract thinking, verbal abilities and cognitive outcomes of students with help or without media tools. This result is also in line with the research conducted by Sockalingam and Schmidt (2011) which says that PBL is used to understand the characteristics of each problem well, and overcome, develop and create individual problem-solving abilities, because problem-solving has a variety of methods to solve it depending in the perspective of each individual, including in learning in the classroom. This is supported by the results of the study of Nariman and Chrispeels (2016) that the influence of PBL makes teachers and students work collaboratively and helps students solve problems based on their knowledge.

The results of previous studies conducted by Destianingsih and Surjono $(2013 ; 2015)$ also said that there was an effect due to the use of the PBL model on learning outcomes, problemsolving skills, and student motivation with considerable significance. According to Simanjuntak $(2012 ; 2014)$, that the application of the PBL model can more effectively improve mastery of material concepts, and the application of problem-based learning models can improve knowledge and skills in problem-solving. As for the obstacles in this research there are learning facilities, which are inadequate in the school, and the schedule of activities in the school, as well as the schedule of activities in the school which makes the learning process become choked up so that the time period for completing one material becomes long. Researchers also have an obstacle to managing researchers' time while implementing the PBL model, because in the application of the PBL model it is necessary to share the right time during the learning process so that the material and results of the PBL model can be seen optimally.

Based on the discussion of the research results supported by the results of previous researchers proving that the PBL learning model can be used to improve learning outcomes in the cognitive domain and students' problem-solving abilities.

\section{Conclusion}

Based on the results of research obtained from the results of data analysis and hypothesis testing it can be concluded as follows:

1. Test the hypothesis of learning outcomes using the t-test shows 2.56>1.6697, meaning that there is an effect of applying the PBL model to student learning outcomes while for the KPM hypothesis test using the t-test shows 7.36> 1.6697, meaning that there is influence the application of the PBL model to student KPM.

2. Student learning outcomes in the class given learning using the PBL model experienced a better increase of $62 \%$ compared to the conventional class $49 \%$ in the medium category, while for KPM students in the class given learning using the PBL model experienced a better increase of 53\% in the category moderate, compared to conventional class $26 \%$ in the low category.

3. Improvement analysis using N-Gain shows that in the experimental class there is a better increase with the highest increase in indicators making a solution alternative of $86 \%$ in the high category and indicators developing alternative solutions experiencing the lowest increase of $37 \%$ in the medium category, compared to the control class with indicators making alternative solutions obtain a $37 \%$ increase in the medium category and developing alternative solutions obtaining $16 \%$ in the low category.

\section{Suggestion}


Based on the discussion of the results of the study, it is suggested several things as follows:

1. It is expected that teachers who want to apply to learn with a problem-based learning model can optimize the time planned in the learning implementation plan (RPP). Allocations used must really be adjusted to the learning plan that has been made.

2. For researchers who want to research the problem-based learning model, learning is expected to further refine this research, especially in examining attitudes and skills.

\section{REFERENCES}

Anderson, L. W., \&Krathwohl, D. R. (eds.) (2001). A taxonomy for learning, teaching, and assessing: A revision of Bloom's taxonomy of educational objectives. New York: Longman.

Arends, R.I., (2008), Learning to Teach Ninth Edition, New York: Penerbit Mc Graw-Hill Companies, Inc, America.

Destianingsih, E., (2015), Pengaruh Model Problem Based Learning Terhadap Kemampuan Pemecahan Masalah Siswa Pada Pembelajaran Fisika, Jurnal INPAFI, ISSN 2355-7109, 3(1), 1-6.

Joyce, B., Weil, M. dan Calhoun, E., (2009), Models of Teaching: Model-Model Pengajaran, Yogyakarta: Pustaka Pelajar.

Nariman, N., dan Chrispeels, J., (2016), PBL in the Era of Reform Standards: Challenges and Benefits Perceived by Teachers in One Elementary School, Interdiciplinary Journal of PBL, ISSN 1541-5015, 10(1), 1-16.

Nezu, A.M., Maguth, C.N., dan D’Zrurilla, T.J., (2007), Solving Life's Problems, New York: Springer Publishing Company.

Razzak, N.A., (2012) Problem-Based Learning in the Educational Psychology Classroom: Bahraini Teacher Candidates' Experience, International Journal of Teaching and Learning in Higher Education, ISSN 18129129, 24(2), 134-143.

Simanjuntak, M.P., (2012), Penerapan Model Pembelajaran Berbasis Pemecahan Masalah Untuk Meningkatkan Pengetahuan, Keterampilan, Dan Perilaku Metakognisi Mahasiswa, Jurnal Online Pendidikan Fisika, ISSN 2301-7651, 1(1), 1-7.
Simanjuntak, M.P., (2014), Efektifitas Model Problem Based Learning Terhadap Penguasaan Konsep Mahasiswa Pada Konsep Suhu Dan Kalor, Jurnal INPAFI, 2(3), 126-133.

Sockalingam, N., dan Schmidt, H.G., (2011), Characteristics of Problems dor ProblemBased Learning: The Students' Perspective, Interdisciplinary Journal of Problem-Based Learning, 5(1), 6-33.

Surjono, H.D., (2013), Pengaruh Problem-Based Learning Terhadap Hasil Belajar Ditinjau Dari Motivasi Belajar PLC Di SMK, Jurnal Pendidikan Vokasi, 3(2), 178-191.

Uno, H.S., (2006), Perencanaan Pembelajaran, Jakarta: Penerbit Bumi Aksara

Wardhani, K., (2012), Pembelajaran Fisika Dengan Model Problem Based Learning Menggunakan Multimedia Dan Modul Ditinjau Dari Kemampuan Berpikir Abstrak dan Kemampuan Verbal Siswa, Jurnal Inkuiri, ISSN: 2252-7893, 1(2), 163 169. 